\section{DIARY}

\section{JANUARY 2010}

BDA seminar -

Tender training for orthodontists

Date: 15 January 2010

Venue: British Dental Association, London www.bda.org

British Academy of Cosmetic Dentistry Study Club: Impression free dentistry: are we there yet?

Date: 26 January 2010

Venue: British Dental Association, London www.bacd.com

\section{FEBRUARY}

The National Association of Prison Dentistry UK Annual Conference Date: 5 February 2010

Venue: Birmingham Botanical Gardens \&t Glasshouses

www.napduk.org

Dental Forum 2010

Date: 4-6 February 2010

Venue: Vincennes, The Parc Floral, Paris www.dentalforum2010.com

BDA Seminar - Dentistry in the UK

Date: 11 February 2010

Venue: British Dental Association, London www.bda.org

American Institute of Implant Dentistry (AIID): Pathways to excellence in implant dentistry Date: 19-20 February 2010 Venue: Tenerife, Spain www.implant-dentistry.com

\section{MARCH}

\section{AADR/CADR Annual Meeting}

Date: 3-6 March 2010

Venue: Walter E. Washington Convention

Center, Washington DC

http://aadronline.org

The Dentistry Show

Date: 19-20 March 2010

Venue: NEC Birmingham

www.thedentistryshow.co.uk

World of Health IT Conference and Exhibition

Date: 15-18 March, 2010

Venue: The Convention Centre, CCIB,

Barcelona

www.worldofhealthit.org

\title{
PRIZES IN RISK MANAGEMENT COMPETITION
}

Around 300 dental professionals gathered to hear topical lectures on body dysmorphia and patient expectations at this year's Premier Symposium, a risk management event created for all members of the team.

Organised by Dental Protection and Schülke, the event also featured the Premier Awards 2009. This annual risk management competition has a total prize fund of £6,000 and accepts entries from projects which recognise the importance of patient safety.

The undergraduate prize went to Richard Beckwith for his paper Difficulties in obtaining valid consent in clinical dentistry, with Rachel Ingle in second place for her study A comparison of HTM01-05 guidance with the sterilisation of reusable instruments in the Dental Practice Unit, University of Sheffield.
The Postgraduate prize went to Flt Lt James Roberts for his paper An audit to assess the cleanliness and storage of decontaminated dental instruments and second prize was received by Richard Holliday for Dental record keeping and the role of oral cancer screening in the dental access centre.

The DCP prize was awarded to Michelle Mitchell for Ethical considerations in 21st century dental hygiene while second place prize was awarded to Amy Wilkins for Extending the role of the dental nurse in the orthodontic practice: the patients' perspective.

Kevin Lewis, Dental Director of Dental Protection said, 'The awards focus on raising the awareness and management of risks within the practice, and we are delighted that so many of this year's entries were so relevant to many of the hot topics in UK dentistry.'

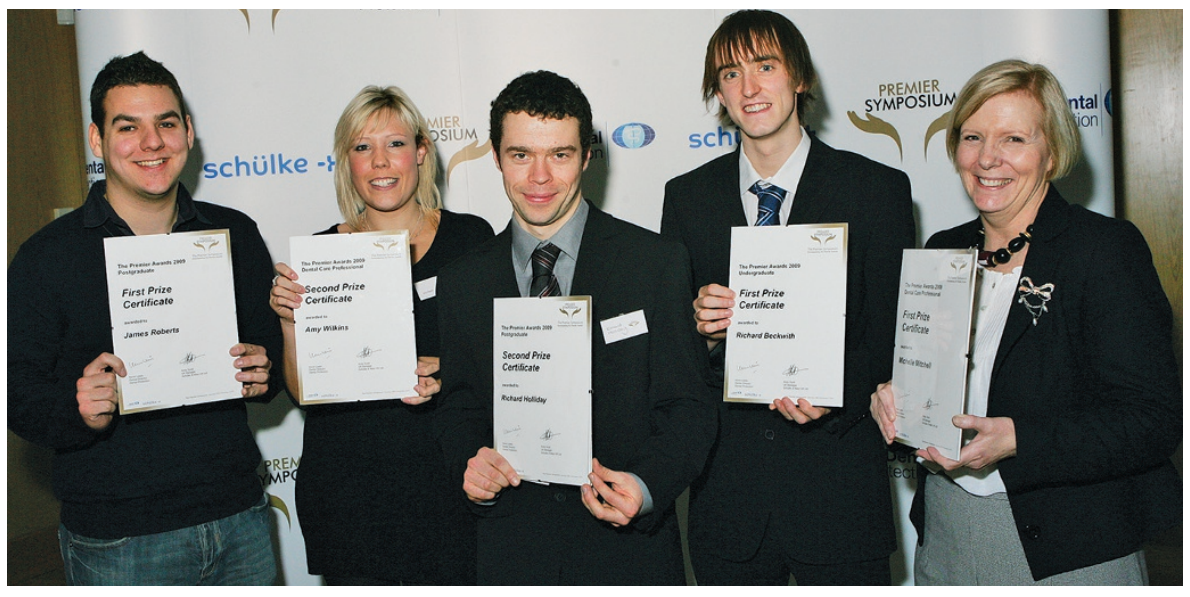

\section{NEW GDC CHAIR ELECTED}

Alison Lockyer has been elected as the new Chair of the Council of the General Dental Council.

Alison Lockyer qualified in Edinburgh in 1980 and works full-time as a primary care dentist. She is a returning registrant member of the Council and was appointed earlier this year by the Appointments Commission after the Council underwent a restructuring to become smaller and fully appointed.

For the first time its make up evenly reflects the people that provide and receive dental care, with 12 professional members and 12 lay members. The cur- rent Chair Hew Mathewson and the Chair Elect Alison Lockyer will discuss and agree a detailed handover timetable.

The Chair Elect will take office as Chair on either 1 January 2010 or on the date on which the current Chair resigns, by agreement, whichever is earlier.

Current Chair Hew Mathewson said, 'There are more exciting and challenging times ahead for the GDC and Alison, a dentist registrant member of Council, brings with her a wealth of leadership experience. Working with the GDC's new Interim Chief Executive I am confident she will do much to strengthen the Council's commitment to patient protection.' 